\title{
TESTING OF THE DIFFERENTIAL URBANIZATION MODEL IN UKRAINE
}

\author{
'Kostyantyn MEZENTSEV, ${ }^{2}$ Oleksii HAVRYLIUK \\ 1,2Taras Shevchenko National University of Kyiv, Ukraine \\ 'k_mez@ukr.net, ${ }^{2} g o k 777 @ u k r . n e t$
}

\begin{abstract}
During the last decade studies of cities in Ukraine are characterized by greater skewness toward descriptiveness, loss of relation with the key theories and concepts that explain urban development in general and in conditions of post-socialist transformations in particular. Experience of urban researches of many post-socialist countries shows the growing importance of theorizing and conceptualization of various aspects of urban development. So now the important task is to return the Ukrainian urban studies toward integration into the global theoretical discourse.

Thus, it is worth to consider the concept of differential urbanization. H.S. Geyer \& T. A. Kontuly proposed theoretical model of differential urbanization, which was tested on the example of several countries. Is it possible in Ukraine identifying the typical stages of the differential urbanization? What is the sequence of stages of differential urbanization in Ukraine? How similar time-limits of stage of differential urbanization in Ukraine and other countries for which the model has already been tested? These questions will be answered in the article.
\end{abstract}

Key words: urbanization, stage of urbanization, stage concept of urbanization, model of differential urbanization, Ukraine.

UDC: 911.3

\section{ТЕСТУВАННЯ МОДЕЛІ ДИФЕРЕНЦІАЛЬНОї УРБАНІЗАЦІї В УКРАЇНІ}

\author{
'Костянтин МЕЗЕНЦЕВ, ²Олексій ГАВРИЛЮК \\ 1,2Київський начіональний університет імені Тараса Шевченка, Україна \\ ${ }^{1}$ __mez@ukr.net, ${ }^{2} g o k 777 @ u k r . n e t$
}

\begin{abstract}
Анотація: Протягом останнього десятиліття дослідження розвитку міст в Україні характеризується все більшим перекосом в бік описовості, втратою зв'язку із ключовими теоріями і концепціями, що пояснюють розвиток міст в цілому та в умовах постсоціалістичних трансформацій зокрема. Досвід урбаністичних досліджень багатьох постсоціалістичних країн свідчить про зростання ролі теоретизації та концептуалізації різних аспектів розвитку міст. Тому нині важливим завданням $\epsilon$ повернення українських урбаністичних досліджень в бік інтеграції до загальносвітового теоретичного дискурсу.

Так, варто розглянути концепцію диференціальної урбанізації. Г. Ґейєр та Т. Контуллі запропонували теоретичну модель диференціальної урбанізації, яку було протестовано на прикладі ряду країн. Чи можливо в Україні виділити типові стадії моделі диференціальної урбанізації? Якою є послідовність стадій диференціальної урбанізації в Україні? Наскільки подібними за часовими межами $\epsilon$ стадії диференціальної урбанізації в Україні та інших країнах щодо яких дана модель вже тестувалася? На ці питання буде дано відповідь у даній статті.

Ключові слова: урбанізація, стадії урбанізації, концепції стадійного розвитку урбанізації, модель диференціальної урбанізації, Україна.
\end{abstract}

удк: 911.3

\section{Постановка проблеми}

Урбанізація - багатоаспектний суспільнопросторовий процес підвищення ролі міст в житті суспільства, концентрації населення у міських поселеннях, поширення міського способу життя. Як i будь-який інший суспільно-просторовий процес, він характеризується стадійністю та циклічністю розвитку. В західній географічній літературі ще з 1960-х років тривають наукові дискусії щодо стадійності урбанізації, пропонуються численні варіанти стадій (фаз) урбанізації (наприклад, [11, $14,16])$. В радянській літературі у другій половині 1980-х років, коли зростання міст загальмувалось, також звернули увагу на стадійні схеми розвитку урбанізації [13].

Першою (за часом формулювання) можна вважати концепцію Дж. Джіббса (1963) [19]. Наслідуючи його, ряд дослідників запропонували свої стадійні

(c) К. Мезенцев, О. Гаврилюк схеми урбанізації та розселення, які в різних ступенях детальності фіксували фази змін тенденцій i динаміки розвитку агломерацій та позаагломераційних територій. Саме за таким принципом виділено шість стадій урбанізації П. Холлом [11], а згодом чотири стадії урбанізації в розвитку агломерацій (метрополітенських регіонів) Л. Клаассеном та Г. Шимемі [16]. Стадійна концепція урбанізації зазнала подальшої модифікації в працях Л. Ван ден Берга, Л. Клаассена та ін. [36] стосовно опису стадій та головних ознак позиціонування розвитку міст. При цьому варто відмітити, що поряд із стадійністю її трактують як своєрідний циклічний процес, який на певному етапі суспіль-ного розвитку ніби повертається до вихідної позиції (початкової точки), починаючи принципово новий цикл, але на якісно новому витку (в якісно новому вимірі) [9].

3 точки зору вивчення стадійної еволюції регіонального розвитку, важливим доробком $\epsilon$ розвинуті у 1990-х роках концепції російських 
географів - самоорганізації міського розселення В.Шупера та синхронності просторової еволюції систем розселення та транспортних мереж А.Валесяна [30; 34; 35]. Зокрема, А.Валесян встановив взаємозв'язок між еволюцією систем розселення (що описується одразу у двох аспектах - як еволюційні зміни центральних місць і як зміни стадій урбанізації) та еволюцією транспортних мереж, підтвердив гіпотезу про співпадіння критичних періодів у їх просторовій еволюції. В. Шупер вважає, що співпадіння у часі глибоких змін ієрархічної будови систем центральних місць (поява нового рівня ієрархіï) і переходу системи розселення на нову стадію еволюції за Дж. Джіббсом, $є$ важливим для географічного світогляду результатом [31].

У сучасній вітчизняній фаховій літературі варто згадати роботи Г. Підгрушного, який акцентує увагу на циклічному характері урбогенезу та пов'язаному 3 ним формуванні полюсів соціально-економічного розвитку. Вчений визначив часові рамки проходження в економіці України чотирьох циклів КондратьєваШумпетера та відповідно чотирьох хвиль урбогенезу, пов'язаного $з$ масовим виникненням нових поселень, що набули статусу міст [24].

Зважаючи на різний характер змін у динаміці чисельності населення міських поселень різного розміру поряд із класичними стадійними концепціями урбанізації у 1980-90-х роках поширення отримали концепції диференціальної урбанізації (наприклад, [6; 8; 27]). Проте, на думку Т. Нєфьодової та А. Трейвіша, сутність не змінилася: концентрація i деконцентрація населення, чергуючись, диференціюють міграції i зростання поселень різного розміру - «вверх чи вниз по ієрархіï»[22]. Важливим кроком у розвитку урбаністичної географії було тестування запропонованої Г. Гейєром та Т. Контуллі теоретичної моделі диференціальної урбанізації [8] на матеріалах ряду країн, зокрема Західної Німеччини (Т. Контулі, Б. Деарден), Великої Британії (Т. Чемпіон), Італії (С. Боніфаці, Ф. Хейнс), Фінляндії (Е. Хейккіля), Естонії (Т. Таммару), Росії (Т.Нефьодова, А. Трейвіш), Туреччини (А.Гедік), Індії (Д. Мукхерджі), Ботсвани (Т. Д. Джвібу) у різні періоди розвитку $[2,3,7,12,17,18,20,21,32,33]$.

В українській географії тестування моделі диференціальної урбанізації ще не проводилося, що зумовлює актуальність даного дослідження. Тому метою роботи $є$ аналіз теоретичної бази моделі диференціальної урбанізації та ㄲi тестування щодо реалій України у період 1840-2014 pр. такі:

Ключовими дослідницькими питаннями були

- Чи можливо в Україні виділити типові стадії моделі диференціальної урбанізації?

- Якою є послідовність стадій диференціальної урбанізації в Україні?

- Наскільки подібними за часовими межами $є$ стадії диференціальної урбанізації в Україні та інших країнах щодо яких дана модель вже тестувалася?

\section{Теоретичний бекграунд}

Розглянемо основні підходи щодо виділення стадій урбанізації. Так, Дж. Джіббс виділив п'ять стадій урбанізації [14, 29] (рис. 1). Перша стадія характеризується відносно рівномірним розселенням населення (диференційованим у відповідності до природних ландшафтів); появою окремих міст у неурбанізованій (сільській) місцевості; зростанням чисельності як міського, так і сільського населення (тобто частка міського населення коливається зростає за рахунок появи нових міст та знижується при значному переважанні сільського населення). На другій стадіï міський спосіб життя стає більш привабливим порівняно із сільським, що стимулює міграції до міст із сільської місцевості, як наслідок, відбувається швидке зростання міст, чисельності та частки міського населення (міське населення зростає швидше, ніж сільське, проте сільське населення також продовжує зростати). Для третьої стадіï характерне «насичення» міст (передусім внаслідок приросту за рахунок мігрантів із сільської місцевості), що зумовлює формування навколо найбільших 3 них приміських зон, появу міських агломерацій. При цьому головні міста зростають швидше, ніж передмістя, а сільське населення в результаті значного міграційного відпливу починає скорочуватись. Для четвертої стадї характерний розвиток процесів субурбанізації (більш швидкий порівняно 3 головними містами розвиток приміської зони, що стає міграційно привабливою для міських жителів); скорочення чисельності сільського населення. На n’ятій стадї̈ посилюється деконцентрація міського населення, уповільнюються темпи росту міських агломерацій, зростає концентрація населення на позаагломераційних територіях, але наближених до міських агломерацій (що зумовлює в деяких районах формування урбанізованих районів і мегаполісів); сільське населення зростає, проте сільський спосіб життя уподібнюється до міського; частка міського населення складає понад 75\% всього населення.

Хоча ця концепція і стала «революційною» щодо розуміння розвитку процесів урбанізації, проте Дж. Джіббс вказував на асинхронне протікання даних фаз у регіонах з різним рівнем розвитку. Так, наприклад, в країнах, що розвиваються, переважає концентрація, а в розвинутих країнах деконцентрація населення [22].

Л. Клаассен та Г. Шимемі [16], Л. Ван ден Берг, Л. Клаассен та ін. [36], зважаючи на напрямки міграції та процеси, що відбуваються у міському ядрі, окраїнах і хінтерланді, запропонували виділення чотирьох стадій урбанізації в межах метрополітенських регіонів (рис. 2). Перша стадія - урбанізащія, що розглядається як процес швидкого зростання чисельності міського населення, концентрації населення, робочих місць, виробництва, сфери послуг у головному місті (метрополісі), в той час як внаслідок міграційного відтоку хінтерланд втрачає населення. Цей процес традиційно пов'язаний iз індустріалізацією, переселенням сільських жителів до міст внаслідок кращих можливостей працевлаштування, умов життя, вищого рівня 


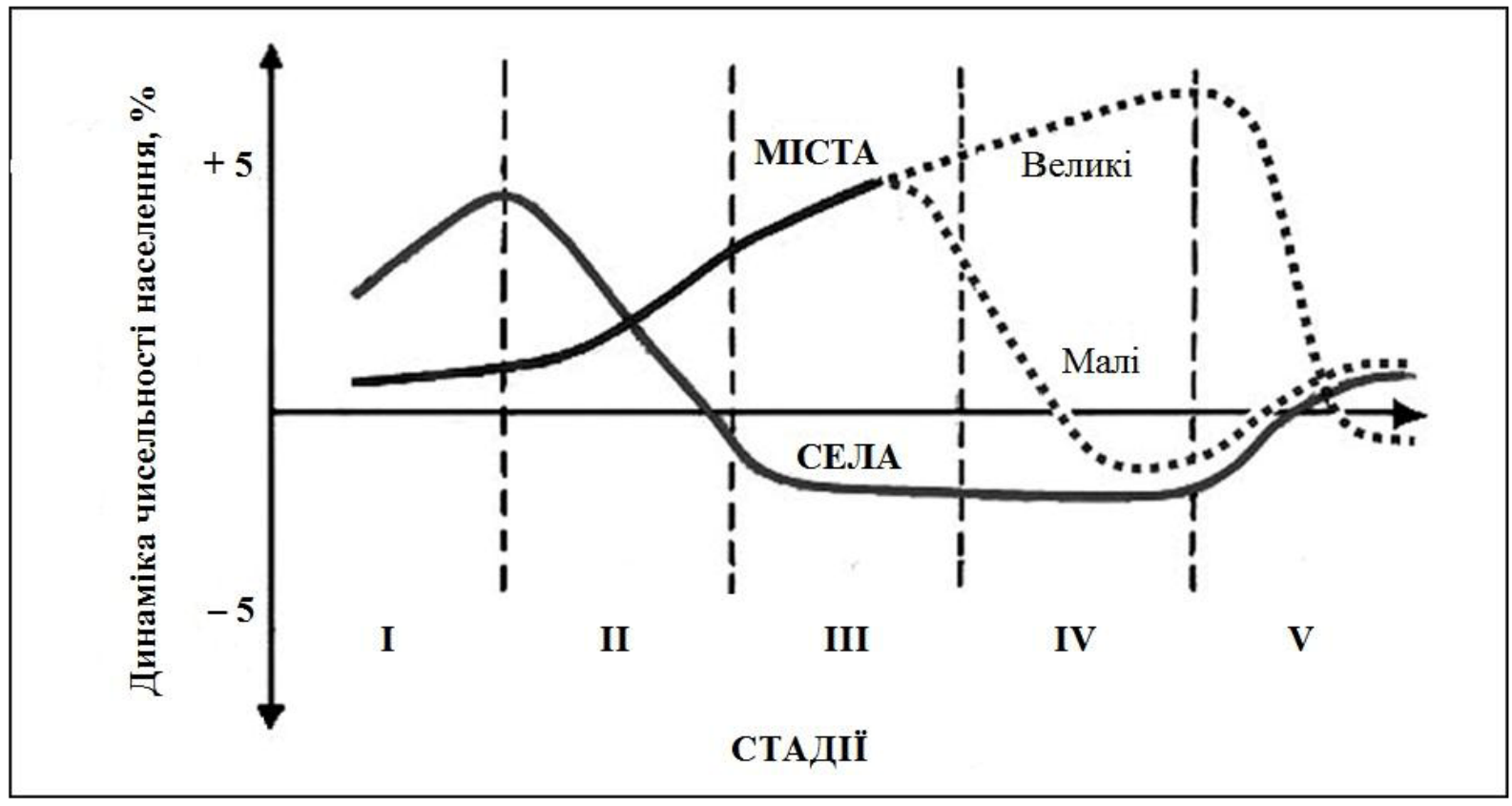

Рис. 1. Стадії розвитку урбанізації за Дж. Джіббсом, 1963 [14; 29].

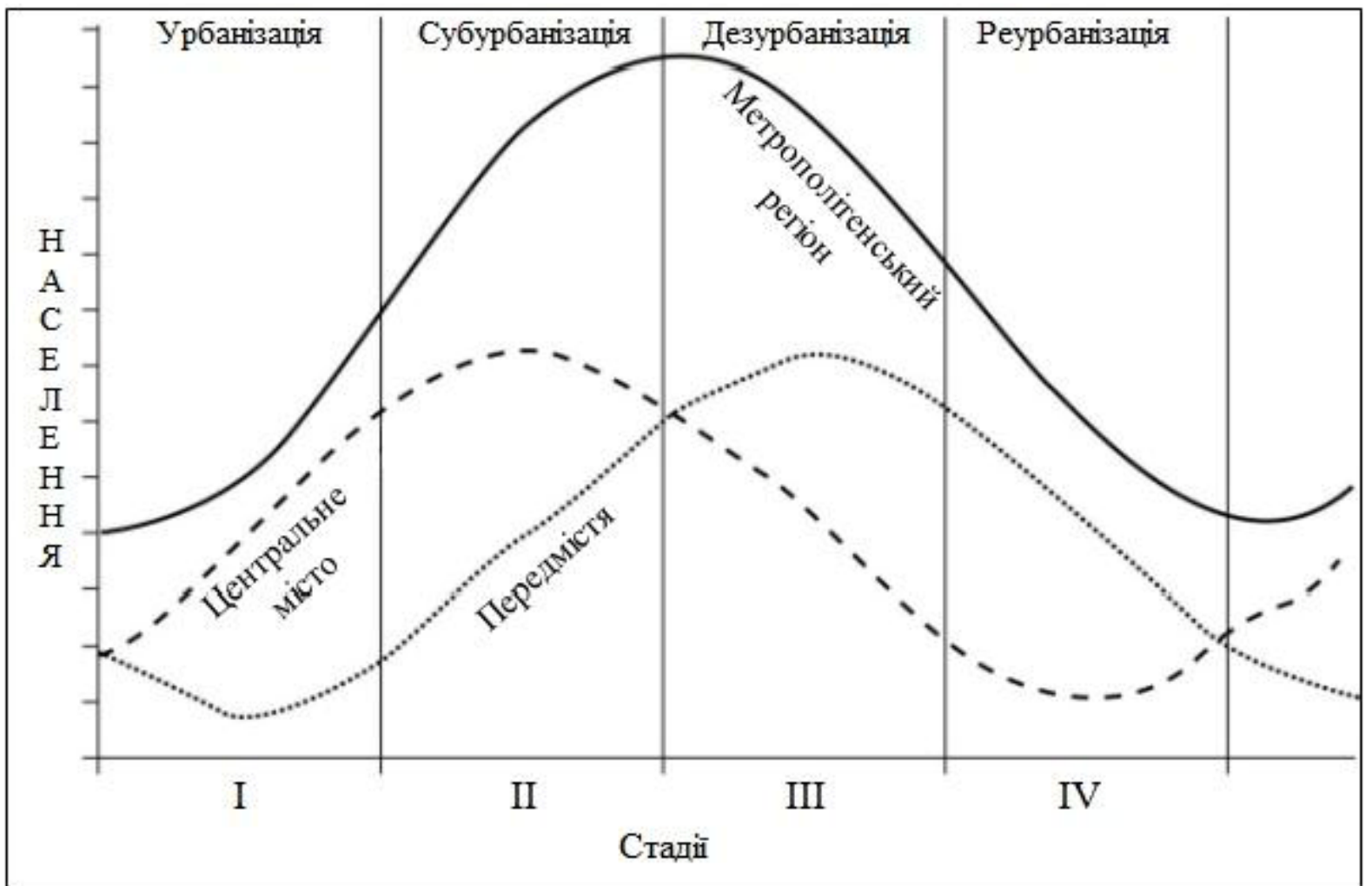

Рис. 2. Стадії урбанізації в метрополітенському регіоні за Л. Ван ден Бергом та ін., 1982 [15; 36].

доходів тощо. Друга стадія - субурбанізація - процес «якісного вдосконалення» урбанізації, що зумовлює переселення міських жителів до менших поселень поряд 3 метрополісом із кращими умовами життя (чистіше довкілля, менша щільність населення, приватний будинок та ін.). Приміська зона зростає швидше головного міста, але при цьому мешканці субурбії тісно зв'язані з метрополісом, продовжують працювати та отримувати більшість послуг у ньому. Чисельність населення головного міста продовжує зростати передусім за рахунок хінтерланду. Третя стадія - дезурбанізація - процес переселення міських жителів за межі субурбії до невеликих міст та сільських поселень. Поступово там створюються нові робочі місця, розвивається власна сфера послуг. Як наслідок, головне місто, а подекуди й субурбія втрачають населення. Зростання спостерігатися в окремих поселеннях на периферії. Четверта стадія реурбанізація - повернення населення передмість до метрополіса внаслідок джентрифікації та ревіталізації індустріальних зон в центральній частині міста, наближення місця проживання до місця роботи. 
Як наслідок, відбувається зростання чисельності населення головного міста, або скорочення населення в ньому повільніше, ніж в субурбії.

Наступна схема стадій урбанізації запропонована в теоретичній моделі диференціальної урбанізації $[8,17,18]$ (рис. 3). Для кожної стадії характерні специфічні співвідношення балансів міграції чи індексів динаміки населення трьох категорій центрів: головних міст, середніх (проміжних) і малих (лише малих міст або всіх поселень). Конкретні критерії їх визначення різняться між собою. Часові межі стадій визначаються перетином будь-якої пари кривих. Пари стадій формують три головні епохи - 1) урбанізації, 2) поляризаційної реверсї (polarization reversal, або оберненої поляризаціiі), 3) контрурбанізації [22].

В межах епохи урбанізації виділяють початкову стадію крупноміської урбанізачії (У-I), що характеризується пришвидшеним зростанням великих (головних) міст за рахунок малих і особливо середніх, та зрілу стадію крупноміської урбанізаціі (У-II), коли спостерігається зростання великих міст, а втрати населення малими містами досягають максимуму; середні міста також починають зростати, приваблюючи мігрантів.

Епоха поляризаційної реверсії охоплює початкову стадію росту середніх міст (ПР-III), коли за темпами зростання лідирують середні міста, великі міста стрімко втрачають свою атрактивність, а малі - ¥ї нарощують, та зрілу стадію росту середнix мiсm (ПP-IV), що характеризується найвищими темпами зростання малих міст (які, проте, ще не випереджають середні), а великі міста втрачають населення.
Епоха контрурбанізації включає початкову стадію росту малих міст (КУ-V), які зростають швидше за інші, а середні міста втрачають атрактивність; 3 ними після проходження мінімальних значень, зближаються головні, та зрілу стадію росту малих міст (КУ-VI), коли середні міста відстають від малих і головних, хоча вже не дуже сильно і ненадовго.

Перші дві стадії крупноміської урбанізації характеризуються концентрацією населення, наступні чотири стадії поляризаційної реверсії та контрурбанізації - деконцентрацією. Шоста стадія завершує перший (великий) цикл розвитку урбанізації. Потім все повертається до вихідного порядку «великі - середні - малі». Однак, як видно 3 рис. 3, 3 часом спостерігається осциляторне (таке, що коливається) стискання кривої із зменшенням амплітуди по обох осях: зменшується як тривалість стадій, так і розриви між типами міст. Тому реурбанізація - перша стадія наступного циклу відрізняється від початкової стадії крупноміської урбанізації першого циклу. Загальна мобільність населення, часта зміна міграційних циклів (із великих міст і назад при їх джентрифікації) поєднуються зі стійко сформованою ієрархією поселень.

В цілому варто зазначити, що нові стадіальні схеми урбанізації мало що додали до розуміння соціальних коренів сучасних форм урбанізації, а спираються на класичні роботи Б. Беррі та інших авторів [1] щодо міграційної і розселенської сегрегації (відтоку з «тісних» і «хворих» міст, заповнених бідним і «кольоровим» населенням, найзаможніших, a потім i середніх верств, створення ними в передмістях і більш віддалених поселеннях малих

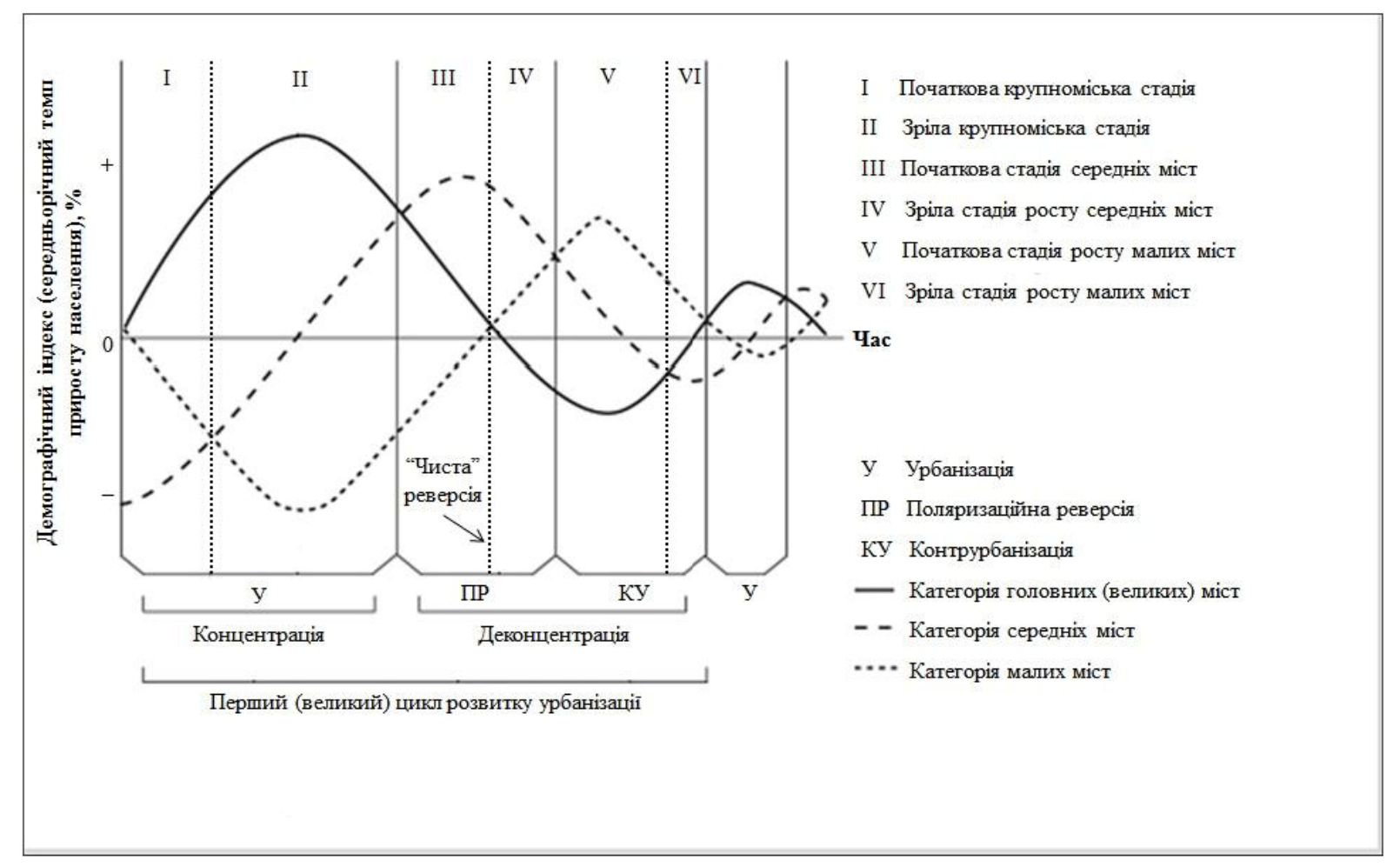

Рис. 3. Модель диференціальної урбанізації. «Універсальна» схема за Контулі та іншими, 1993 (за [4; 17]). 
фірм 3 IT-інфраструктурою та мобільним зв'язком, що зменшує потребу і залежність від великого міста, як на стадії субурбанізації) та «вікових циклів» (за схемою: народився в передмісті, навчався та почав кар'єру у великому, одружився, виїхав з родиною в приміську зону або віддалене поселення, наприклад, народився у Бучі чи в Ірпені, отримав вищу освіту та почав кар'єру в Києві, після одруження виїхав 3 родиною до Вишневого чи Броварів). Проте важливою перевагою таких моделей $є$ можливість їх адаптації до реальної ситуації в умовах обмеженості статистичних даних.

\section{Методичні аспекти дослідження}

Першим важливим моментом тестування моделі диференціальної урбанізації є визначення критеріїв виділення великих, середніх і малих міст. Для різних країн i регіонів вони відрізняються. Наприклад, середніми для Франції визначали міста від 10 до 100 тисяч осіб, а для країн, що розвиваються, від 50 до 400 тисяч. Тому, використовуючи підхід Т. Нефьодової та А. Трейвіша [22], в даному дослідженні застосовано змінну величину для віднесення міст України до категорії середніх, що відповідає «ковзній» шкалі (рис. 4): до 1897 року - 5-20 тис осіб; у 1897-1926 pp. - 10-50 тис осіб; у 1926-59 pp. - 20-100 тис. осіб; у 1960-х рр. - 40-200 тис. осіб; починаючи з 1970 року - 50-250 тис осіб, оскільки більші міста в останні десятиліття були, як правило, регіональними центрами і ядрами агломерацій.

Другий важливий момент - визначення ключового показника. У разі відсутності даних щодо сальдо міграції, для побудови моделі Т. Нефьодова та А. Трейвіш пропонують розраховувати індекси динаміки населення за певний (наприклад, десятирічний) період. У такому разі, якщо населення всюди зростає або всюди скорочується, криві можуть бути зміщені вгору або вниз, але їх форма відображатиме принципові зміни, що не вплине на ідентифікацію стадій. Зрозуміло, що не можна виключати специфічних «збоїв» (коли, наприклад, у Німеччині до кінця війни населення, ховаючись від бомбардувань, виїжджало з міст). Але тоді, «чи то забігши вперед, чи то здавши назад, розселення повернеться до “нормальної” стадії. Інше питання - як скоро?» [22]. Отже, зважаючи на тривалість досліджуваного періоду, в роботі використано лише індекси динаміки чисельності населення (середньорічні темпи приросту населення), а не сальдо міграції.

Методика розрахунку індексів динаміки населення враховувала можливість переходу міст протягом досліджуваного періоду із однієї категорії в іншу, тобто в дослідженні використовуються категорії міст змінного складу (динамічні, за західною термінологією). Територіальні межі України до 1991 року в даному дослідженні визначалися в складі українських губерній Російської імперії та УРСР в складі СРСР.

Ідентифікацію стадій моделі диференціальної урбанізації в Україні здійснено 3 урахуванням доступності статистичних даних за період 1840-2014 pp. та певних історичних подій (фактів), які виступали відповідними індикаторами зміни стадій. Джерельну базу дослідження становили офіційні дані Державної служби статистики України (www. ukrstat.gov.ua), дані семитомного видання «Городские поселения в Российской Империи» (1860-1864); таблиці щодо стану міст Російської імперії (http:// dlib.rsl.ru/viewer/ 01003542943\#page2?page=1); результати статистичних досліджень Російської імперії К. Германа (СПб, 1819); статистичні таблиці про стан міст Російської імперії (СПб, 1842); дані «Статистическиого временника Российской империи» (СПб, 1866), статистичного щорічника Росії за 1914 рік; економіко-географічні нариси В. Семенова-Тян-Шанського «Город и деревня в Европейской России» 3 врахуванням неофіційних міст Семенова-Тян-Шанського (СПб, 1910); статистичні нариси А. Ряшина «Население России за 100 лет (1811-1913 гг.)» (М., 1956); відомості десятитомного видання «Історія Української РСР» (1981-1985); дані Всесоюзних переписів населення 1926, 1939, 1959, 1970, 1979, 1989 років, Всеукраїнського перепису населення 2001 року; відкриті бази даних Демоскоп (зокрема: http://demoscope.ru/weekly/ app/app4087.xls; (http://demoscope.ru/weekly/app/ app4089.xls); http://demoscope.ru/weekly/app/app4004. php) «Мапи України» (http://ukrmap.org.ua /Statistika nasel_ukr.htm) та «Cities\&towns of Ukraine» (http:// pop-stat.mashke.org/ukraine-cities.htm).

\section{Тестування моделі «диференціальної урбанізації» в Україні (1840-2014)}

На основі обрахованих індексів динаміки чисельності населення в розрізі трьох категорій міських поселень (великі, середні та малі) та сільського населення в цілому за період 1840-2014 pр.

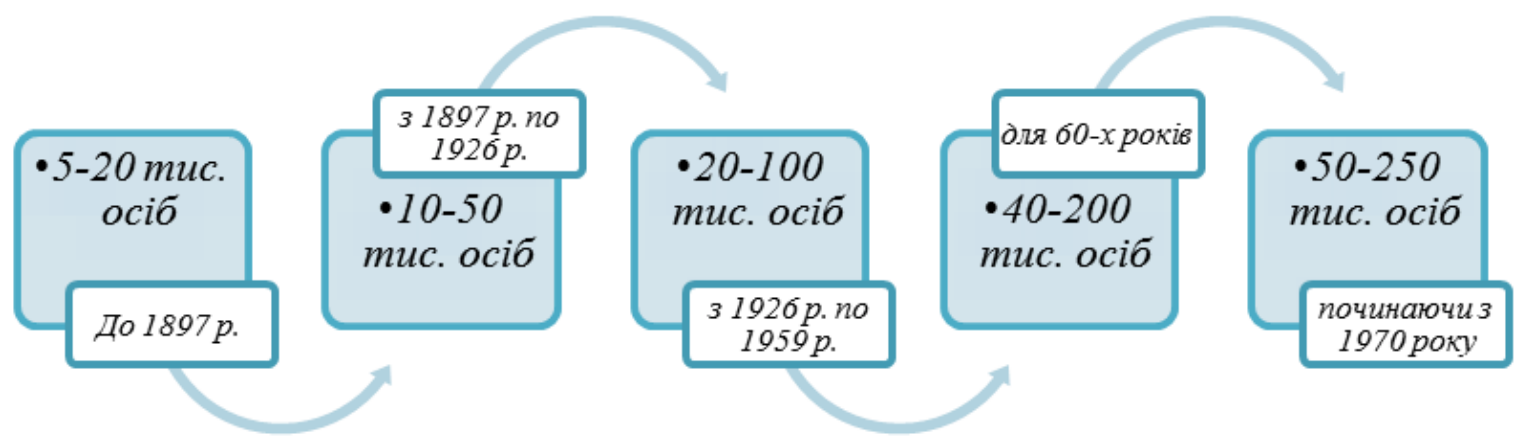

Рис. 4. «Ковзна» шкала середніх міст (за [22]). 
побудовано графічну модель розвитку урбанізації в Україні (рис. 5). Як бачимо, реальна ситуація в Україні істотно відрізняється від теоретичної моделі (рис. 3). Її варто розглядати в якості першого кроку 3 виявлення стадій диференціальної урбанізації, а отже, інтерпретувати 3 обачністю. «Батьки» моделі диференційної урбанізації (Т. Контулі та Г. Гейєер) акцентують увагу на тому, що слід дотримуватися обережності при застосуванні моделі до реальності, оскільки часова характеристика моделі диференціальної урбанізації відноситься до ідеальної ситуації, де в міських регіонах спостерігається рівномірний розподіл природних ресурсів. Також при тестуванні необхідно ретельно враховувати локальні умови історії розвитку і занепаду міст в розрізі певних груп (в нашому випадку - трьох категорій) [18].

Таким чином, враховуючи вищезазначене, було ідентифіковано стадії диференціальної урбанізації 3 урахуванням відповідних суспільно-історичних умов, в яких вони відбувалися. Аналіз показав, що за період 1840-2014 рр. Україна пройшла через такі стадії (табл. 1): початкову стадію крупноміської урбанізації (У-I), зрілу стадію крупноміської урбанізації (У-II), початкову стадію поляризаційної реверсії (ПР-ІІІ) та стадію так званої кризової деконцентрації населення (контрурбанізації, $К У)$.

Розглянемо суспільно-історичні умови, що дозволили чіткіше ідентифікувати стадії диференціальної урбанізації в Україні.

Перша початкова стадія крупноміської урбанізації 1840-1870-х рр. (У-I) починається від 1840-х і до 1870-х років характеризується зростанням чисельності населення у великих містах, що було зумовлено початком промислової революції (зокрема, будівництвом залізниць, фабрик, заводів, шахт як нового визначального містоутворюючого фактора), державними реформами (зокрема, скасування кріпацтва та ін.) та виникненням нових міст. Безумовно дестимулятором розвитку урбанізації (особливо в південних губерніях) була Кримська війна (1853-56), після якої у 1856 році одне велике місто (Ізмаїл) та два середніх (Рені, Кілія) перейшли до складу Молдавського князівства, васала Туреччини.

У пореформені часи спостерігається якісно новий етап урбанізації: відбувається перехід (186070-ті рр.) від початкової крупноміської (У-I) до зрілої крупноміської стадії урбанізації (У-II). Остання тривала до початку Першої світової війни. В цей період відбувається зростання концентрації населення у великих та середніх містах та утворення нових міських поселень, зумовлене бурхливим розвитком капіталізму (індустріалізація, будівництво залізниць тощо), а також демографічним вибухом.
Значну кількість міст на Сході та Південному Сході України засновано в ХІХ ст. (що пов'язано 3 будівництвом вугільних шахт, металургійних, машинобудівних та інших заводів, початком експлуатації родовищ залізної руди Криворізького i марганцевої руди Нікопольського басейнів). Розвитку міст Центральної України сприяло будівництво підприємств харчової, легкої, цегельної промисловості. Негативний вплив мали соціальнополітичні суперечності 1900-х років.

Варто зазначити, що ідентифікація у період 1870-1914 рр. зрілої стадії крупноміської урбанізації (У-II) передусім пов’язана із кривою, що відображає динаміку чисельності населення великих міст, проте криві трендів малих та середніх міст $\epsilon$ нехарактерними для цієї стадії. Це зумовлено, поперше, суттєвою статистичною «прогалиною», що певним чином деформує криві на графіку (статистичні дані взяті за 1858 рік та за переписом населення 1897 року, тобто з різницею у близько 40 років), подруге, тим, що були враховані так звані неофіційні малі та середні міста (за В. Семеновим-Тян-Шанским), що також відобразилось на міжгруповому розподілі міст, по-третє, утворенням багатьох малих міст, що поступово перетворювались у середні, особливо в кінці XIX - на початку XX століть.

3 початком Першої світової війни на українських землях почались процеси кризової деконцентрації населення, які завершились приблизно в 1923 році, адже 1914-1921 pр. - це період міждержавних громадянських конфліктів, що супроводжувався соціально-економічною кризою, сецесійними та анексійними процесами, значними військовими втратами, голодом 1921-1923 pp. та численною еміграцією (внаслідок міграції відбувалось різке зменшення чисельності населення у містах). Дана стадія кризової деконцентрації населення $(K У)$ чітко прослідковується на графічній моделі (див. рис. 5), коли всі криві різко повертають до низу, перетинаючи нульову відмітку.

Після утворення УРСР (1922) в складі СРСР знов ідентифікується початкова стадія крупноміської урбанізації $(У-I)$, що зумовлено відбудовою господарства, новою економічною політикою (19211928 рр.) та запровадженням планової економіки, i як результат - форсованою індустріалізацією. Також відбувалась зміна цензу міст, що зумовило перетворення деяких сіл на міста, а містечок - на села. Таким чином відбулось синхронне підняття кривих всіх категорій міст та сільських поселень вище нульової відмітки.

У 1939-1941 рр. з'явилися ознаки переходу три-валої початкової стадії крупноміської урбані-

Таблиия 1

Ідентифікація стадій диференціальної урбанізації в Україні

\begin{tabular}{|c|c|c|c|c|}
\hline \multicolumn{5}{|c|}{ Стадія } \\
\hline У-I & У-II & ПР-III & ПР-IV & Кризова КУ \\
\hline $1840-1870$ & $1870-1914$ & & & $1914-1923$ \\
$1923-1939$ & $1939-1941$ & & & $1941-1950$ \\
$1950-1959$ & $1959-1990$ & $1990-1993$ & & \\
\hline
\end{tabular}




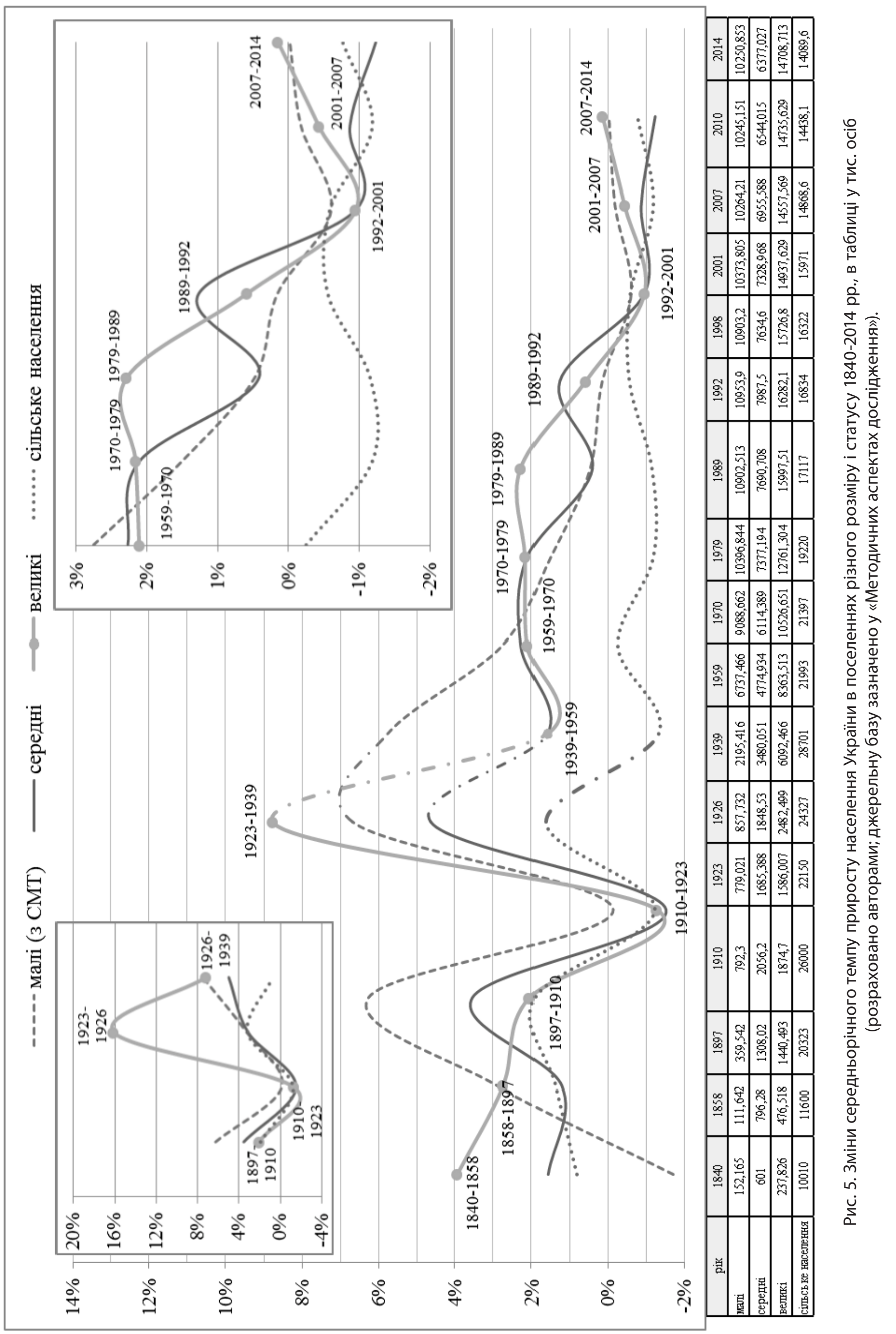


зації (У-I) у зрілу стадію (У-II). Проте зміна адміністративно-територіального устрою УРСР загальмувала цей процес, оскільки в приєднаних західних областях України переважали дуже малі міста із порівняно слабкою економічною базою. Саме тому період 1939-1941 рр. доцільно розглядати як перехідну стадію крупноміської урбанізації (У-I/У-II $\approx \mathrm{Y}-I I)$.

Надалі стадійний розвиток урбанізації на території України був перерваний Другою світовою війною, що призвела до руйнування міст (спалено та зруйновано 714 міських поселень [5, с. 188]). Після закінчення війни розпочалася відбудова міського господарства, створено ряд нових міст. Проте на фоні післявоєнної відбудови спостерігались негативні явища та процеси: голод 1946-47 pp., колективізація західноукраїнських земель і заслання за «антирадянські політичні злочини» тощо. Ускладнюючим моментом є відсутність достовірних статистичних даних у розрізі виділених категорій поселень (на графіку це відображено відрізками штрих-пунктиром). Спираючись на історичні факти та доступні узагальнені статистичні дані, період 1941-1950 рр. ідентифіковано як стадію кризової деконцентрації населення $(К У)$.

1950-1959 рр. характеризуються зростанням природного приросту населення, зміною критеріїв віднесення населених пунктів до категорії міських (1956 р.), остаточним формуванням території України з приєднанням Криму в 1954 році. Цей період ідентифіковано як чергову початкову стадію крупноміської урбанізації (У-I).

Після 1959 р. починається бурхливий розвиток урбанізаційних процесів: виникнення значної кількості нових міст і селищ міського типу (3 1946 до 1970 р. мережа міських поселень збільшилася на 128 міст та 516 смт [25]), що зумовило «домінування» на графічній моделі у 1959-1970-х рр. кривої малих міст (разом 3 смт) (див. рис.5). Упродовж 19591979 рр. сформувались основні агломерації УРСР, виникла категорія міст-мільйонерів; частка міських жителів у 1960-х роках перевищила 50 \%, повільно збільшуючись до кінця 1990-х років [28, с. 34-38]. Стрімке зростання великих міст спонукає до політики «регулювання росту» великих міст починаючи 3 1960-х років, що певним чином пояснює синхронність трендів розвитку великих та середніх міст в цей період. Таким чином, у 1959-1990 pp. ідентифіковано зрілу стадію крупноміської урбанізації (У-II). Окрему увагу слід звернути на криву динаміки сільського населення (див. рис. 5). Так, темпи його приросту починаючи з 1959 р. є від'ємними, що згідно концепції Дж. Джіббса (див. рис. 1), є ознакою урбанізації і свідчить про те, що міста стають атракторами міграційних потоків 3 сільської місцевості, тобто відбувається перехід від фази початкової урбанізації до фази агломераційної урбанізації, що в свою чергу $€$ також певним ідентифікатором старту зрілої стадії крупноміської урбанізації (У-II) саме 3 кінця 1950-х - початку 1960-x pp.
Період розпаду СРСР та здобуття Україною незалежності можна ідентифікувати як перехід від зрілої стадії крупноміської урбанізації $(У-I I)$ до початкової стадії поляризаційної реверсії (ПРIII), коли середні міста починають нарощувати свою атрактивність, що свідчить про більш-менш «природню» деконцентрацію населення порівняно 3 попередніми періодами. У 1992 р. вперше у повоєнний час зареєстровано депопуляцію в міських поселеннях. Таким чином, 1990-1993 pp. - початкова стадія поляризаційної реверсії (ПР-III). Втрати за рахунок природного скорочення населення в містах упродовж 1992-1993рр. частково компенсувалися міграційним припливом, але вже 1994 року в Україні спостерігаються і негативне сальдо міграції міського населення, тобто роль міграцій як компенсатора депопуляції в міській місцевості вичерпалася [26].

Із середини 1990-х років демографічна ситуація в міських поселеннях України характеризується посиленням депопуляції населення. Пік цієї тенденції припадає на кінець 1990-х - початок 2000-х років. За період з 1989 до 2011 р. при зростанні частки міського населення на 1,8\%, його кількість зменшилась на 3,1 млн. осіб $(9,1 \%)$. Тобто індекси динаміки населення в розрізі трьох категорій міст та сільського населення, починаючи 3 середини 1990-х років, вже не відображають доцентрові чи відцентрові процеси в дихотомії «село-місто», а лише показують загальні тенденції депопуляції та від'ємного сальдо міграції. Також на загострення цих процесів вплинули соціально-економічні трансформації (зміна економічної системи, виникнення і посилення соціальної стратифікації населення, економічні кризи 1990-х та 2008-2010 pp. тощо). Хоча порівняно $з$ початком 1990-х років кількість міст в Україні збільшилась на 26, змінився розподіл міст за людністю: два міста втратили статус мільйонера (Донецьк, Дніпропетровськ), чотирнадцять середніх за людністю міст (переважно моноспеціалізованих) перейшли в категорію малих.

Отже, в пострадянський час, починаючи 3 середини 1990-х років і до кінця досліджуваного періоду, ідентифікувати домінуючу стадію диференціальної урбанізації 3 використанням індексів динаміки чисельності населення неможливо. 3 метою ідентифікації стадій доцільно дослідити сальдо міграції в розрізі трьох категорій міст (рис. 6).

Як видно з рис. 6, після 2005 року спостерігався період стійкого зменшення міграційної атрактивності великих містприповільномузростанніпривабливості малих міських поселень. 2010-2011 рр. можна було б вважати початком поляризаційної реверсії, але у подальшому сальдо міграційного приросту у великих містах знов значно зросло. Тобто і показник сальдо міграції не дозволяє чітко ідентифікувати стадії диференціальної урбанізації у пострадянський період.

Таким чином, 1994-2014 рр. - період, в якому відбуваються пертурбаційні процеси, що зумовлено соціальними, економічними, політичними та демографічними умовами протікання урбанізації. 


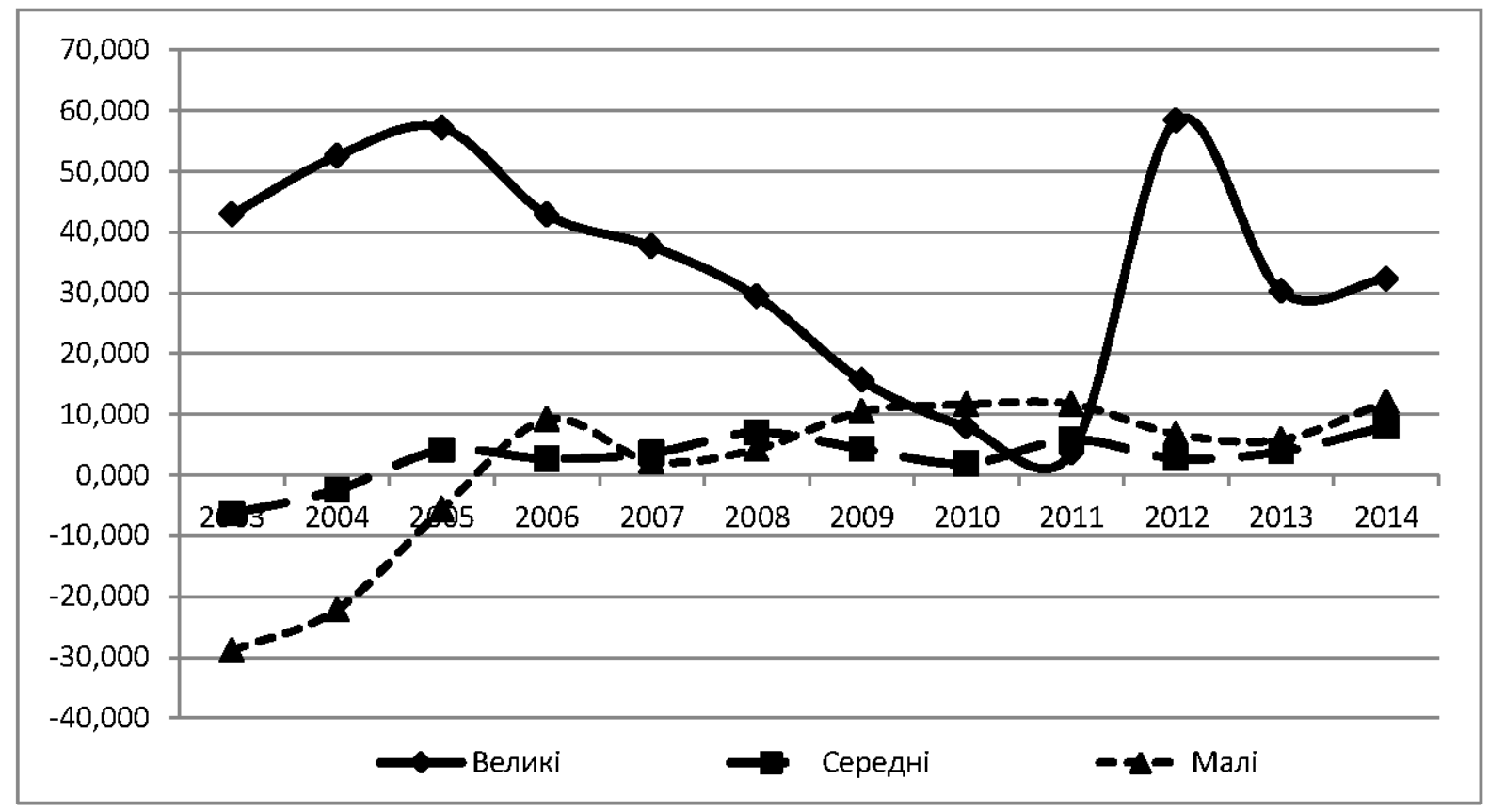

Рис. 6. Динаміка сальдо міграції у міських поселеннях України в 2003-2014 роках (розраховано авторами)

Таблиия 2

Результати тестування моделі диференціальної урбанізації в розвинутих країнах та країнах, що розвиваються (за $[2 ; 3 ; 7 ; 12 ; 17 ; 18 ; 20 ; 21 ; 32 ; 33])$

\begin{tabular}{|c|c|c|c|c|c|}
\hline \multirow{2}{*}{ Країна } & \multicolumn{3}{|c|}{$\begin{array}{c}\text { Перший цикл } \\
\text { розвитку урбанізації }\end{array}$} & \multirow{2}{*}{$\begin{array}{c}\text { Другий цикл } \\
\text { розвитку } \\
\text { урбанізації }\end{array}$} & \multirow{2}{*}{$\begin{array}{c}\text { Тип } \\
\text { проходження } \\
\text { стадій /циклів } \\
\text { моделі }\end{array}$} \\
\hline & $\begin{array}{l}\text { Урбанізація } \\
\text { (У-I, У-II) }\end{array}$ & $\begin{array}{c}\text { Поляризаційна } \\
\text { реверсія } \\
\text { (ПР-III, ПР-IV) }\end{array}$ & $\begin{array}{c}\text { Контр- } \\
\text { урбанізація } \\
\text { (КУ) }\end{array}$ & & \\
\hline Фінляндія & 1941-1955 & $1955-1965$ & $1965-1975$ & 1990-1998 & I \\
\hline Італія & 1921-1971 & 1971-1999 & & & \multirow{4}{*}{ II } \\
\hline Туреччина & $1955-1980$ & 1980-1997 & & & \\
\hline $\begin{array}{l}\text { Південна } \\
\text { Африка }\end{array}$ & $1951-1980$ & 1980-1991 & & & \\
\hline Індія & 1961-1981 & 1981-1991 & & & \\
\hline Естонія & $1950-1990$ & & $1990-2000$ & & III / IV \\
\hline $\begin{array}{l}\text { Велика } \\
\text { Британія }\end{array}$ & $1921-1931$ & $1901-1921$ & 1931-1991 & & \multirow{4}{*}{ IV } \\
\hline $\begin{array}{l}\text { Німеччина } \\
\text { (Західна) }\end{array}$ & $1950-1961$ & $\begin{array}{l}1961-1970 \\
1987-1995\end{array}$ & $\begin{array}{l}1939-1950 \\
1970-1987 \\
1995-2010\end{array}$ & & \\
\hline Росія & $\begin{array}{l}1856-1914 \\
1926-1989\end{array}$ & 1989-1999 & 1914-1926 & & \\
\hline Україна & $\begin{array}{l}1840-1914 \\
1923-1941 \\
1950-1990\end{array}$ & 1990-1993 & $\begin{array}{l}1914-1923 \\
1941-1950\end{array}$ & & \\
\hline
\end{tabular}


Або ж це певною мірою «модельна лакуна» в стадійному розвитку урбанізації, яка ще триватиме певний період. Відкритим залишається питання, скільки триватиме ще цей період і чи відбудеться повернення до теоретичної моделі.

Окремі дослідники відмічають, що для постіндустріального розвитку урбанізації стає необов'язковим послідовне проходження стадій, a можливий «пропуск» окремих стадій або ж їх проходження в «спотвореному» вигляді. Наприклад, в Японії послідовність стадій розвитку урбанізації виглядає так: «урбанізація $\rightarrow$ субурбанізація $\rightarrow$ реурбанізація», тобто стадія дезурбанізації була пропущена [23].

\section{Чи подібна диференціальна урбанізація в Украӥні до інших країн?}

Наскільки подібним є розвиток урбанізації в Україні у порівнянні з іншими країнами, щодо яких тестувалася модель диференціальної урбанізації? Чи тільки для України характерні розриви у поступовому проходженні стадій, процеси кризової деконцентрації населення? Спробуємо дати відповіді на ці запитання. Для цього проаналізуємо результати тестування моделі для дев'яти країн (табл. 2). Важливою ремаркою $є$ те, що ці тестування були здійснені на початку 2000-х років.

Перший тип проходження стадій моделі диференціальної урбанізації характерний для Фінляндії, де в результаті тестування чітко виявлено послідовність стадій першого циклу та «чистий» перехід до другого циклу (табл. 2). Урбанізація у Фінляндії розпочалась відносно пізно у порівнянні 3 іншими європейськими країнами, але мала швидкий темп розвитку. Між 1941-75 рр. Фінляндія швидко пройшла через три стадії моделі: урбанізація (1941-55), поляризаційна реверсія (1955-ح1965) та контрурбанізація (1965-75). Після того, як значення сальдо міграції для всіх трьох категорій міст стали приблизно рівними (1975-90), було зафіксовано початок другого циклу урбанізації, що розпочався у 1990 і тривав до 1998 р. [18].

Другий тип характерний для Італії, Туреччини, Південної Африки та Індії, де розвиток відбувався послідовно від урбанізаційної стадії до поляризаційної реверсії.

Третій тип проходження стадій спостерігається в Естонії: стрибкоподібний перехід одразу до контрурбанізаційної стадії протягом 1990-2000 pp., який пов'язують із значним відтоком мігрантів 3 великих та малих міст на фоні перехідного пострадянського періоду.

Четвертий тип характерний для Великої Британії, Німеччини (Західної Німеччини), Естонії та Росії. Розвиток урбанізації тут чітко не відповідав послідовності стадій моделі. У випадку Німеччини у 1939-50 pp. та Росії у 1914-26 рр. тимчасовий перехід до більш прогресивних стадій моделі (кризової контрурбанізації) пояснюється впливом Першої та Другої світових війн, революцією та громадянською війною в Росії. Проте послаблення політичних та соціально-економічних потрясінь, спричинених війною, зумовило припинення кризової деконцентрації населення i повернення до стадії урбанізації. Якщо повернення до стадії поляризаційної реверсії у Західній Німеччині протягом 1987-1995 рр. пояснюється політичним возз'єднанням Німеччини, то повернення до урбанізаційної стадії у Великій Британії протягом 1921-31 pp. розглядається як відхилення [18].

Отже, в цілому, базуючись на результатах тестування моделі диференціальної урбанізації, можна зробити висновок про доцільність іiі застосування. У п'яти країнах (Фінляндія, Італія, Туреччина, ПАР та Індія) розвиток урбанізації відповідав послідовності переходу між стадіями моделі. Більшість випадків, де послідовність стадій порушувалася, пояснюються «обтяжливими політичними втручаннями, значними змінами політично-економічних умов або особливостями локальних політичних обставин» [18].

Україна за характером зміни стадій найбільш подібна до Німеччини та Росії, де розвиток урбанізації також не відповідає чіткій циклічності стадій моделі диференціальної урбанізації. Ці країни досягли контрурбанізаційної стадії без дотримання послідовності переходу, зважаючи на специфічні локальні політичні, економічні, соціальні та демографічні умови розвитку урбанізаційних процесів.

Проведене дослідження дало можливість відповісти на поставлені на початку роботи питання. Чи можливо в Україні виділити типові стадії моделі диференціальної урбанізації? Так. Тестування моделі диференціальної урбанізації в Україні за період 18402014 рр. дозволило визначити такі стадії: початкову стадію крупноміської урбанізації $(\mathrm{V}-I)$, зрілу стадію крупноміської урбанізації (У-II), початкову стадію поляризаційної реверсії (ПР-ІІІ) та стадію кризової деконцентрації населення $(K У)$.

Якою $є$ послідовність стадій диференціальної урбанізації в Україні? Перехід між стадіями був не завжди чітким. Протягом досліджуваного періоду в Україні спостерігалося три старти урбанізації: перший старт (1840-1923 рр.), що супроводжувався переходом від першої (У-I) до другої (У-II) стадії моделі, а потім стрибком до стадії кризової деконцентрації населення (КУ); другий старт (19231950 рр.), що за послідовністю стадій був подібний до першого старту; третій старт (1950-1993), коли послідовно були пройдені три перших стадії моделі (У-I, У-II та ПР-III). Проте у пострадянський період подальше виділення стадій є неможливим, оскільки розраховані індекси динаміки чисельності населення не відображають доцентрові чи відцентрові процеси в дихотомії «місто-село», а лише свідчать про загальні тенденції депопуляції. Застосування показника сальдо міграції також свідчить про нечіткість змін у привабливості міських поселень різних категорій. У даному разі йдеться про так звану «модельну лакуну» в стадійному розвитку урбанізації України.

Наскільки подібними за часовими межами є стадії диференціальної урбанізації в Україні та інших 
країнах щодо яких дана модель вже тестувалася? Україну слід віднести до четвертого типу країн, щодо яких проводилося тестування моделі диференціальної урбанізації, що характеризується непослідовністю проходження стадій внаслідок специфіки впливу політичних, соціально-економічнихтадемографічних чинників.

\section{References:}

1. Berry B. J. L. (ed.). Urbanization and Counterurbanization. Beverly Hills, Sage Publications, 1976, 334 p.

2. Bonifazi C., Heins F. Testing the Differential Urbanisation Model for Italy. Tijdschrift voor Economische en Sociale Geografie, 2003, Vol. 94(1), pp. 23-37.

3. Champion T. Testing the Differential Urbanisation Model: Great Britain, 1901-91. Tijdschrift voor Economische en Sociale Geografie, 2003, Vol. 94(1), pp. 11-22.

4. Champion T. Urbanization, Suburbanization, Counterurbanization and Reurbanization. Handbook of Urban Studies (Ronan Paddison, ed.). SAGE Publications Ltd, 2001, pp. 143-161.

5. Docenko A. I. Teritorial'na organizaciâ rozselennâ (teoriâ ta praktika) [Territorial organization of settlement system (theory and practice)]. Kyiv, Fenìks, 2010, 536 p. (In Ukrainian).

6. Fielding A.J. Migration and urbanization in Western Europe since 1950. The Geographical Journal, 1989, Vol.155(1), pp. 60-69.

7. Gedik A. Differential Urbanization in Turkey, 1955-97. Tijdschrift voor Economische en Sociale Geografie, 2003, Vol. 94(1), pp. 100-111.

8. Geyer H.S., Kontuly T. A. theoretical foundation of the concept of differential urbanization. International Regional Science Review, 1993, Vol. 15(3), pp. 157-177.

9. Gricaj O. V., Ioffe G. V., Trejviš A. I. Centr i periferiâ v regional'nom razvitii [Center and periphery in regional development]. Moscow, Nauka, 1991, 168 p. (In Russian).

10. Gwebu T.D. Towards a theoretical exploration of the differential urbanization model in Sub-Sahara Africa: the Botswana case. TijdschriftvoorEconomische en SocialeGeografie, 2006, Vol. 97, No. 4, pp. 418-433.

11. Hall P., Hay D. Growth Centers in the European Urban System. London, Heinemann, 1980.

12. Heikkila E. Differential Urbanisation in Finland. Tijdschrift voor Economische en Sociale Geografie, 2003, Vol. 94(1), pp. 49-63.

13. Kûmmel' T. Stadial'naâ koncepciâ urbanizacii: metodologiâ i metody analiza [Stage concept of urbanization: methodology and methods]. Metody izučeniâ rasseleniâ [Methods in population studies]. Moscow, IG AN SSSR, 1987, pp. 82-100. (In Russian).

14. Gibbs J. The evolution of population concentration. Economic Geography, 1963, Vol. 2, pp. 119-129.

15. Kipnis B. A. Polarization, Spread and Upgrading of Urban Functions: From a Smiting 'First City' to a 'Network of Cities’ Structure”. GaWc Research Bulletin, №302. (http://www.lboro.ac.uk/gawc/rb/rb302.html)

16. Klaassen L., Scimemi G. Theoretical issuers in urban dynamics. Dynamics of Urban Development. NewYork, StMartin`s Press, 1981, pp. 8-28.

17. Kontuly T., Dearden B. Testing the temporal characterization of the differential urbanization model in Western Germany over the period 1939-2010. Tijdschrift voor Economische en Sociale Geografie, 2003, Vol. 94(1), pp. 64-74.

18. Kontuly T., Geyer H. Lesson Learned from Testing the Differential Urbanization Model. Tijdschrift voor Economische en Sociale Geografie, 2003, Vol. 94(1), pp. 124-128.

19. Makhrova A. G. Suburbanizaciâ i postsuburbanizaciâ v usloviâh razvitoj aglomeracii (na primere Moskovskoj stoličnoj aglomeracii) [Suburbanization and post-suburbanization in conditions of developed agglomeration (on example of Moscow capital agglomeration)]. Ekkonomika i geografiâ [Economy and geography]. Saint Petersburg, 2013, pp. 211-236. (In Russian).

20. Mookherjee D. Differential Urbanisation Model: The Case of a Developing Country, India 1961-91. Tijdschrift voor Economische en Sociale Geografie, 2003, Vol. 94(1), pp. 38-48.

21. Nefedova T., Treivish A. Differential urbanization in Russia. Tijdschrift voor Economische en Sociale Geografie, 2003, Vol. 94(1), pp. 75-88.

22. Nefedova T.G., Treivish A. I. Teoriâ «differencial'noj urbanizacii» i ierarhiâ gorodov v Rossii na rubeže XXI veka [Theory of differential urbanization and urban hierarchy in Russia at the turn of the twenty-first century]. Problemy urbanizacii na rubeže vekov [Problems of urbanization at the turn of the centuries]. Smolensk, Ojkumena, 2002, pp. 71-86. (In Russian).

23. Phelps N., Wu F. (eds). International Perspectives on Suburbanization: A Post-Suburban World? New York, Palgrave Macmillan, 2011, 312 p.

24. Pìdgrušnij G. P. Značennâ polûsìv socìal'no-ekonomičnogo rozvitku u vdoskonalennì teritorìal'noï organìzaciï suspil'stva [The role of poles of economic development in improvement of territorial organization of society]. Ukraïns' $k i j$ geografičnij žurnal [Ukrainian Geogrpahical Journal], 2013, N. 4, pp. 40-47. (In Ukrainian).

25. Pìtûrenko Û.Ì. Rozvitok mìst i mis'ke rozselennâ v Ukraïns'kìj RSR (Osoblivostì rozvitku ì rozmîsennâ, tipologîâ, teritorìal'nì sistemi ì perspektivi) [Urban development and urban settlement system in Ukrainian SSR]. Kyiv, Naukova dumka, 1972, 188 p. (In Ukrainian). 
26. Pribitkova İ. M. Evolûciâ mìs'kih sistem u časì ì prostorì: ukraïns'kij varìant rozvitku [Evolution of the urban systems in time and space: Ukrainian variant of development]. Mistobuduvannâ ta teritorial'ne planuvannâ [City development and territorial planning], 2011, Vol. 41, pp. 351-368. (In Ukrainian).

27. Richardson H.W. Polarization reversal in developing countries. Papers of the Regional Science Association, 1980, N. 45, pp. 67-85.

28. Salij İ. M. Urbanizaciâ v Ukraïni: social'nij ta upravlins'kij aspekti [Urbanization in Ukraine: social and management aspects]. Kyiv, 2005, 303 p. (In Ukrainian).

29. Simagin U..A. Territorial'naâ organizaciâ naseleniâ [Territorial organization of the population]. Moscow, 2005, 241 p. (In Russian).

30. Shuper V.A. Samoorganizaciâ gorodskogo rasseleniâ [Self-organization of urban settlement system]. Moscow, 1995, 166 p. (In Russian).

31. Shuper V.A. Sinergetičeskaâ revolûciâ v geografii i samoorganizaciâ prostranstva Rossii [Synergetic revolution in geography and self-organizaion of space in Russia]. Strategii dinamičeskogo razvitiâ Rossii: edinstvo samoorganizacii $i$ upravleniâ [Strategies of demographic development of Russia: unity of self-organization and management]. T.3. Sinergetika v rešenii problem čelovečestva XXI veka - dialog škol. Moscow, 2004. (In Russian).

32. Tammaru T. Differential Urbanization and Primate City Growth in Soviet and Post-Soviet Estonia. Tijdschrift voor Economische en Sociale Geografie, 2000, Vol. 91(1), pp. 20-30.

33. Tammaru T. Urban and Rural Population Change in Estonia: Patterns of Differentiated and Undifferentiated Urbanization. Tijdschrift voor Economische en Sociale Geografie, 2003, Vol. 94(1), pp. 112-123.

34. Valesân A. L. Prostranstvennaâ ustojčivost' sistem rasseleniâ i èvolûcionnaâ morfologiâ transportnyh setej [Spatial stability of settlement systems and evolutional morphology of transport networks]. Izvestiâ RAN [Izvestia RN], Ser. Geography, 1994, N. 6, pp. 52-60. (In Russian).

35. Valesân A. L. Sinhronnost'v prostranstvennoj èvolûcii sistem rasseleniâ i transportnyh setej [Synchronicity in the spatial evolution of settlement systems and transport networks]. Author's abstract of PhD Thesis. Moscow, 1995, 46 p. (In Russian).

36. Van der Berg L., Drewett R., Klaassen L.H., Rossi A., Vijverberg C.H.T. Urban Europe: A study of growth and decline. A. Wheaton\&Co. Ltd., Exeter, 1982, 162 p. 